\title{
Charles Darwin University
}

\author{
Eric Fassbender, Andrew Taylor and Peter Houtmeyers
}

\section{Student responses to a work integrated learning approach in a new media teaching unit}

\begin{abstract}
:
This paper describes student responses to the application and integration of a Work Integrated Learning approach to a New Media teaching unit at an Australian university. The purpose of the work-integrated approach was to attempt to teach students how to collaborate in 'real-world' work situations and solve 'real' problems as they occur. Data on student responses and learning outcomes was collected by questionnaires over four semesters. Results show that students respond positively regarding the Work Integrated Learning approach in comparison to traditional coursework based assessment. Students particularly identified their own learning and development in the areas of problem solving, ability to work in a team, analytical skills and their ability to plan and organise, as being positively affected. Furthermore, improvements to student motivation, engagement and overall learning at university are reported.
\end{abstract}

\section{Biographical notes:}

Eric Fassbender's general interests are in the use of virtual environments for teaching, heritage preservation and recreational purposes. He did his $\mathrm{PhD}$ on the effect of music on memory for facts learned in a virtual environment and he is currently working at CDU on the Virtual Galleries research project, which investigates the effect of interactive Art Cameras on art sales in remote communities of the Northern Territory of Australia as well as the usefulness of and 3D Art Galleries for presentation of historically important art exhibitions. Apart from this Eric is working on creating and investigating the usefulness of relaxational and restorative immersive environments for patient recovery. eric@fassbender.com.au

Andrew Taylor's research interests focus on modelling and understanding the population futures of the Northern Territory and remote areas in general. He undertakes formal demographic modelling with a particular interest in Indigenous demographies and economic demography. He has recently completed his Doctorate on the migration futures of Indigenous Territorians. His Masters thesis examined the marketplace for tourism informatics with a view to improving the statistical literacy of regional tourism ventures and systems. andrew.taylor@cdu.edu.au 
Peter Houtmeyers is an education professional with fifteen years experience in the audio, multimedia and education industries. Peter has worked in dual sector VET and Higher Education with diverse groups of students and staff in Australia and Dubai in a co-ordinator and team leader capacity. He has a passion for all things audio spending most of his early career as a post-production audio engineer working for Channel 9 and $\mathrm{ABC}$ in Sydney. Peter is currently teaching at Charles Darwin University where he coordinates both VET and Higher Education new media courses. Peter's research interests include the soundtrack as a narrative entity, prosumer culture and the mashup generation and explorations in remix. peter.houtmeyers@cdu.edu.au

\section{Keywords:}

work integrated learning - multimedia - student project management - collaborative student project - real-world projects 


\section{Introduction}

The purpose of the study reported here was to investigate student perceptions of a work integrated learning (WIL) approach, as applied in a new media and multimedia undergraduate unit at an Australian university. The aim of enacting the WIL approach in this unit was to attempt to teach undergraduate students 'real-world' skills and to assess whether and why the WIL style of teaching might be favoured over traditional coursework (TC) approaches. This paper summarises the findings of our study and puts these findings into the context of research conducted more widely into WIL in higher education.

\section{Background}

Work integrated learning broadly describes an approach to teaching whereby students learn knowledge that is directly relevant to a particular profession. However, this statement could apply to many other approaches to learning and teaching. The concept of WIL goes back to at least 1938 when John Dewey states that 'all genuine education comes about through experience' (1998: 259). A more contemporary description of WIL comes from Cooper Orrell and Bowden who describe WIL as a practice where 'students are exposed to real-world problems that typically represent the variety of work a professional might experience in their particular field of practice' (2010: 45). One of the consistent features of WIL includes that students acquire specific and tacit knowledge about a particular workplace, which is something that cannot be taught in a classroom-based unit (Cooper et al. 2010). Thus, WIL seems to be a feasible approach to teach the younger generation to engage with the real-world challenges in the many professions.

In the area of design, Franz describes WIL as a program where academic learning and professional learning are combined as part of 'a student's formal course of study' (2007: 1). Weisz and Smith present a definition that not only embraces the essence of the descriptions above but is, we believe, the definition that best describes the goals of student learning in the unit in which we integrated the WIL concept. They state that

The key to learning, particularly deep level learning, through work integrated learning, however, rests on the students' ability to reflect on the work experiences, to integrate these experiences with their academic lessons and to conceptualise their learning so that they are able to ultimately bring together their work and their academic experiences to solve problems in unfamiliar environments (Weisz \& Smith 2005: 605).

It is this reflective learning that we aimed to provide to students so that they could apply the concepts, values and discipline knowledge that they learned in our unit in their (work) lives.

Many approaches to WIL are described in the educational and other literature. For example, Freestone, Williams, Thompson and Trembath investigated the experiences and levels of satisfaction of urban planning students who participated in a WIL program that involved direct training within industry. Their main finding was that the overall level of satisfaction with the work placement was high (2007: 357) and that 
'there is evidence to demonstrate that real-world learning in the workplace has a positive impact on students' overall learning, and that motivation and engagement are also enhanced significantly' (5). This study was of particular interest to us as it used a work experience questionnaire (WEQ), which we adapted for the purposes of our study $^{1}$, in order to evaluate student perception of this WIL unit as compared to other learning approaches.

In the area of music technology, Draper and Hitchcock describe a WIL pilot project that places students in workplaces within the creative industries discipline (such as in radio and television broadcasting) (2006). The results were perceived as largely positive, and not just by students but also by the workplace partners. Draper and Hitchcock conclude with a number of recommendations for the expansion and improvement of their WIL program, stating that they believed it worthy of future continuation.

Another example is Bates who describes a WIL approach where undergraduate students participate in a work-placement program as part of their final semester in a Bachelor of Arts (Criminology and Criminal Justice) (2008). The areas where students are placed include policing, corrections, crime research, juvenile justice, crime prevention, early intervention welfare programs, and policy and legislation. Interestingly, the program features three 2-hour compulsory workshops prior to the practicum itself that teach students useful skills for life after their graduation, including job searching, resume writing and how to present themselves in interviews. The data in Bates' study was collected over a ten-year period (1994-2004) and a major finding was that students reported significant learning experiences. These were expressed in students' journal entries, such as:

[I]t has finally occurred to me that this project can have an effect on someone and ... may indeed help someone. At first I felt ... [that] this was a huge responsibility to give to a university student but now, the more I get into it, the more I realise that this is what uni has been preparing me for (qtd. in Bates 2008: 311).

It is not, however, just students and educators who want to see more WIL in the curriculum. Billet and Henderson report that there are increasing expectations from government, industry, professional bodies and students for university-supplied education that is more closely aligned to the needs of specific occupations (2011). Furthermore, they emphasise the need for students to learn the generic skills of selfdirected learning, reflexive critical thinking and the ability to work independently as well as interdependently with others (ibid). Work integrated learning units offer students exactly this learning as they use real-world scenarios and challenges to develop these skills. One of Billet and Henderson's conclusions is that 'providing and integrating experiences in practice settings are increasingly seen as being indispensable components of the higher educational curriculum for many sectors' (2011: 2). Billet states that there is a growing trend amongst universities (internationally) to align their teaching programs more closely with the preferred occupations of their students and they describe this form of education as 'higher vocational education' (2011: 85). 
Professional work integrated learning (that is, learning that is related to professions) includes examples like law, commerce, nursing, medicine, dentistry, social work, physiotherapy and pharmacy (Billett \& Henderson 2011, Cooper et al. 2010). However, 'changing patterns of technology have altered the demand for particular occupations and skills, and require that employees' skill and knowledge level be developed continuously' (Billett \& Henderson 2011, Cooper et al. 2010: 4). Thus, although the push for work-integrated learning is not something that is new to higher education, it is just now being requested by, and applied across, a broader range of graduate occupations. Despite some disadvantages, for example, that the planning and implementation of WIL projects/units is very time consuming (Mellor 1991), WIL is 'seen by universities both as a valid pedagogy and as a means to respond to demands by employers for work-ready graduates' (Patrick et al. 2008). After all, WIL students' chances of finding employment after finishing their education are higher than with purely classroom-based teaching (Harvey et al. 1997, in Orrell 2004).

\section{Method}

The WIL approach was applied to teaching the New Media Design - Advanced Studio unit (NMD302) at Charles Darwin University from 2008 to 2011. Charles Darwin University (CDU) is a relatively small university located in the tropical north of Australia. Its campuses service the urban population of Darwin with coverage also into very remote parts of the Northern Territory (see Figure 1). The unit forms part of undergraduate degrees in the Bachelor of Creative Arts and Industries and while the unit has been taught for a number of years, it had not previously been evaluated formally. Student responses were obtained over four semesters via questionnaires handed out towards the end of each semester.

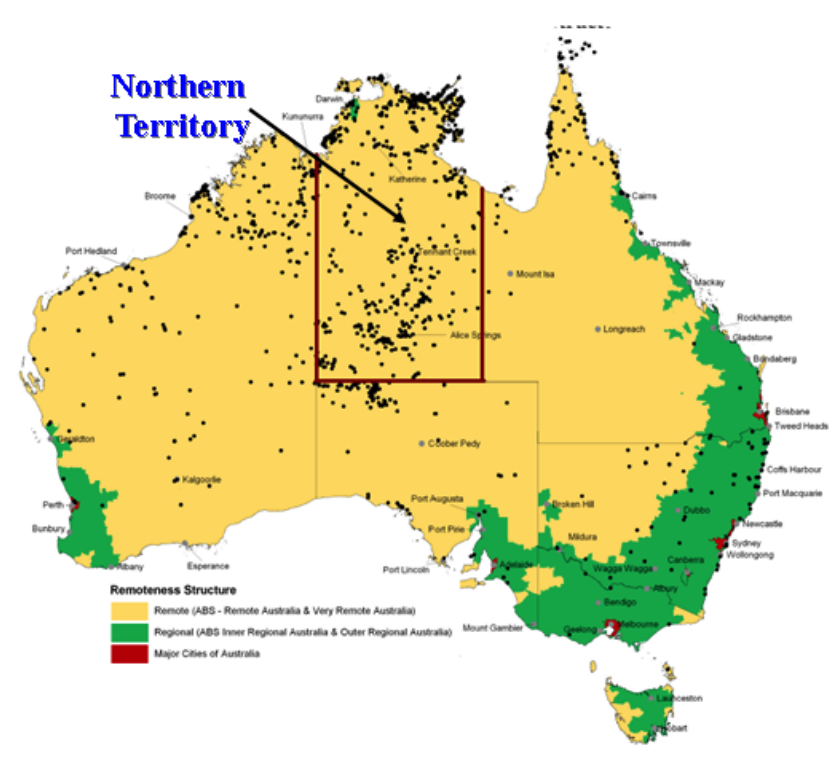

Fig. 1. The Northern Territory of Australia is serviced by Charles Darwin University (Taylor 2012)

A WIL approach was used to teach project management and collaboration skills in the unit from 2008 to 2009 and we were interested in investigating students' perceptions 
and attitudes towards this approach. Freestone et al.'s investigations reported in 2007 were found to be relevant including their use of Work Experience Questionnaires (WEQ), which could be adapted to fit the specific characteristics of the unit under investigation (NMD302). Changes were made to the WEQ according to Gardner and Martin's work on this subject, which suggests a number of minor, but important, changes in the phrasing of a number of questions (2007). Gardner and Martin point out that Likert scale style questionnaires can have a tendency to 'lump' in certain parts if the questions are phrased ambiguously. For example, if a Likert scale is used for an 'either/or' style question (e.g. 'In this placement I was not seen as an extra pair of hands but as a developing professional') the answers tend to lump at the two extremes ('Not at all' and 'Completely') creating a U-shaped response graph. Furthermore, Gardner and Martin point out that there is a risk of biasing responses if questions are phrased so that the desired or expected rating is used in the question. An example in the WEQ was 'My academic supervisor was extremely supportive', which may be interpreted that it is almost a pre-condition that supervisors are extremely supportive. There were some such questions in the WEQ and in our case we rephrased the question to 'How supportive was your lecturer in this WIL Unit as compared to a TC Unit?'. The possible answers then ranged from 'Much less supportive' to 'Less supportive' to 'About the same' to 'More supportive' and 'Much more supportive'. Apart from this, there were some questions in the WEQ that were not directly applicable to our own study as the Freestone et al.'s study involved direct placement of students inside another organisation and in the NMD302 unit students still performed most of their work in the computer labs of the university (i.e. videos were shot outside the classroom but most of the pre-production planning and postproduction editing were done in the classroom). An example of such a non-applicable question is 'My work-based supervisor tried to make the work experience interesting', which is not relevant as students in NMD302 did not have a work supervisor as such. A small number of these questions were either removed or adapted to suit the current study.

After adaptation of the WEQ for our study, the questionnaire covered the following themes: Unit goals (1 question); Support for learning (3 questions); Generic skills (5 questions); Tasks (5 questions); Additional generic skills (7 questions); and, Teaching preference (1 question). The full questionnaire is provided below (see Endnote 1).

The questionnaire was administered to students of the unit after completion of each of 4 semesters (2010-11). The questionnaire was self-completed and anonymous. The first questionnaire was distributed to students via email. Despite the fact that students were asked to submit the completed questionnaires to an independent administrator within the school, the response rate this first semester was only 3 out of 8 students. This is possibly due to students feeling that their responses may be identifiable even though the lecturer involved stated that responses were being anonymised by the administrative staff member. For this reason, the questionnaire was subsequently handed out at the very end of the last class of the unit in semesters 2, 3 and 4 (for convenience we use semesters 1-4 rather than semester 1-2, 2010 and semester 1-2, 2011) and collected in non-specific order in front of students, to assure students of 
their anonymity.

Although all projects involved video production and the associated phases of preproduction, production and post-production, the topics of each semester's WIL varied as new projects were identified each semester. Students worked as a team on one or two group projects depending on the type and scope of the projects. One key element of the unit was that one of the students was elected as the project manager, thus learning the tools and skills that are required in this role. This student was supervised by the lecturer, with close communication ensuring that all students were given guidance on how to approach the different project phases, tasks and allocation of resources. In Semester 1, students worked on artist and manager interviews for a printmaking and art gallery that is located on the campus of Charles Darwin University (CDU). During Semester 2, students created a promotional video for the School of Creative Arts and Humanities, which involved gathering media from the various areas of specialisation within the school and subsequent editing of the video. In Semester 3, students liaised with the library on the CDU campus to create instructional videos for the library website. These videos included how to borrow books or extend loan periods, as well as how to print and access the library catalogue and databases. As can be seen, the clients in these 3 semesters were outside the host school, however, they were still on-campus. This changed in Semester 4, when two external organisations asked for assistance with their projects. These two projects were producing videos for the Darwin Festival and TEDx Darwin. To enable us to work with both clients, the student cohort was split to work on both projects in parallel. Again, a project manager was assigned for each group and supervised by the lecturer. In the projects for Semesters 3 and 4, clients were encouraged to attend classes as often as possible to ensure close communication between all stakeholders. This approach proved highly effective and was praised by students and the clients.

\section{Results}

The results of the questionnaire presented below are from surveys distributed in all four semesters. The mean age of the 36 respondents was 22.5 years, and the distribution of gender was $53 \%$ female and $47 \%$ male.

On average, students said that they found the expected levels of work in the WIL unit comparable to TCU units (A1) (Table 1). In terms of motivation (B1), students answered that they were more motivated to do their best work in the WIL unit and that they received better feedback on their work (B2). Further, in terms of classroom support, the lecturer in the WIL unit was perceived as being more supportive than in a TCU (B3). Importantly, the WIL approach rated highly in the areas of developing problem solving skills $(\mathrm{C} 1)$ and developing the ability to work in a team (C3), however, these areas were the only areas in which the WIL scored more than four out of five (Figure 2). The results augur well for the WIL unit's capacity to help develop workforce-ready students. Indeed, the highest support for the WIL approach was garnered from questions relating to generic skills (see Figure 3). Here, students answered that their analytical skills were sharpened more in the WIL unit (C2). They 
felt more confident about tackling unfamiliar problems (C4) and developed a stronger ability to plan and organise (C5). In terms of being seen as 'an extra pair of hands', students were fairly neutral (D1), however, they tended to disagree that they were asked too many things in the WIL unit that required no thought (D2). Notably, students agreed that the workload was more in the WIL unit than in a TCU (D3).

Students were neutral about any perceived improvement of written communication skills (D4). They, however, reported that their skills in oral communication (D5) increased slightly (3.5). Their reported willingness to learn was higher in the WIL unit (E1) as was their perceived ability for flexibility and adaptability (E2). Reported selfconfidence was rated higher (E3), as was independent judgment (E4). Students also answered that their ability to be creative was higher in the WIL unit (E5) and they thought that their skills to implement change had developed more as well (E6). Students' desire to continue learning in the future was higher (E7) than in a TCU. Lastly, students almost unanimously (32 out of 34 valid responses $=94 \%$ ) answered that they preferred the WIL unit's teaching style in terms of gaining experiences and knowledge which they believed would support them in finding employment in the creative arts industries. We set out these results in a table and figures below.

\section{Summary analysis for item responses}

A1 Expected Standard of Work

B1 How motivated to do best work?

B2 Feedback received

B3 Lecturer Supportive

C1 Develop Ability to solve problems

C2 Sharpen analytical skills

C3 Develop ability to work as team member

C4 How confident about tackling unfamiliar problems

C5 Develop ability to plan and organise

D1 Extra pair of hands?

D2 Too many things involved no thought

D3 Workload

D4 Improved Skills in written communication

D5 Improved skills in oral communication

E1 Willingness to learn

E2 Flexibility and adaptability

E3 Self-confidence

E4 Independent judgement

E5 Ability to be creative

E6 Skills to implement change

E7 Desire to continue learning in future

E8 WILU or TCU

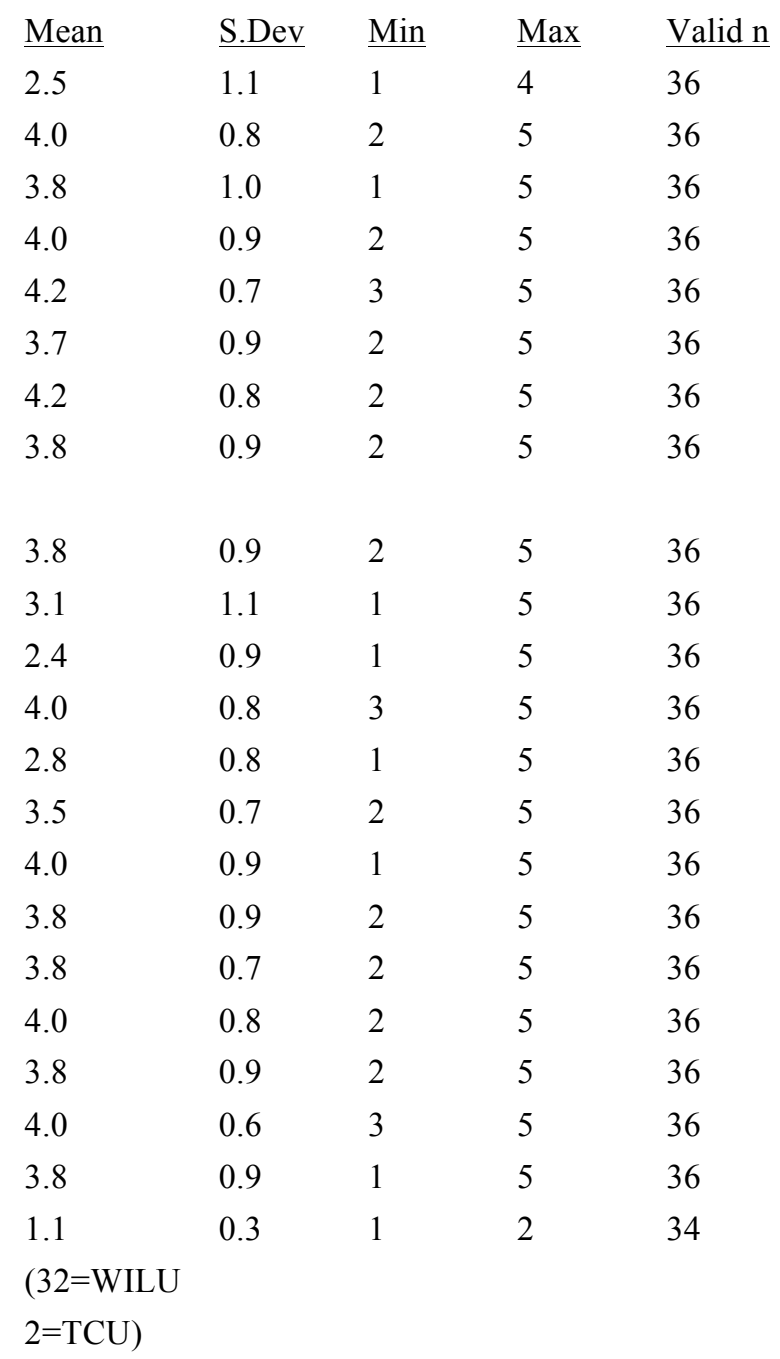


Table 1. Summary analysis for item responses

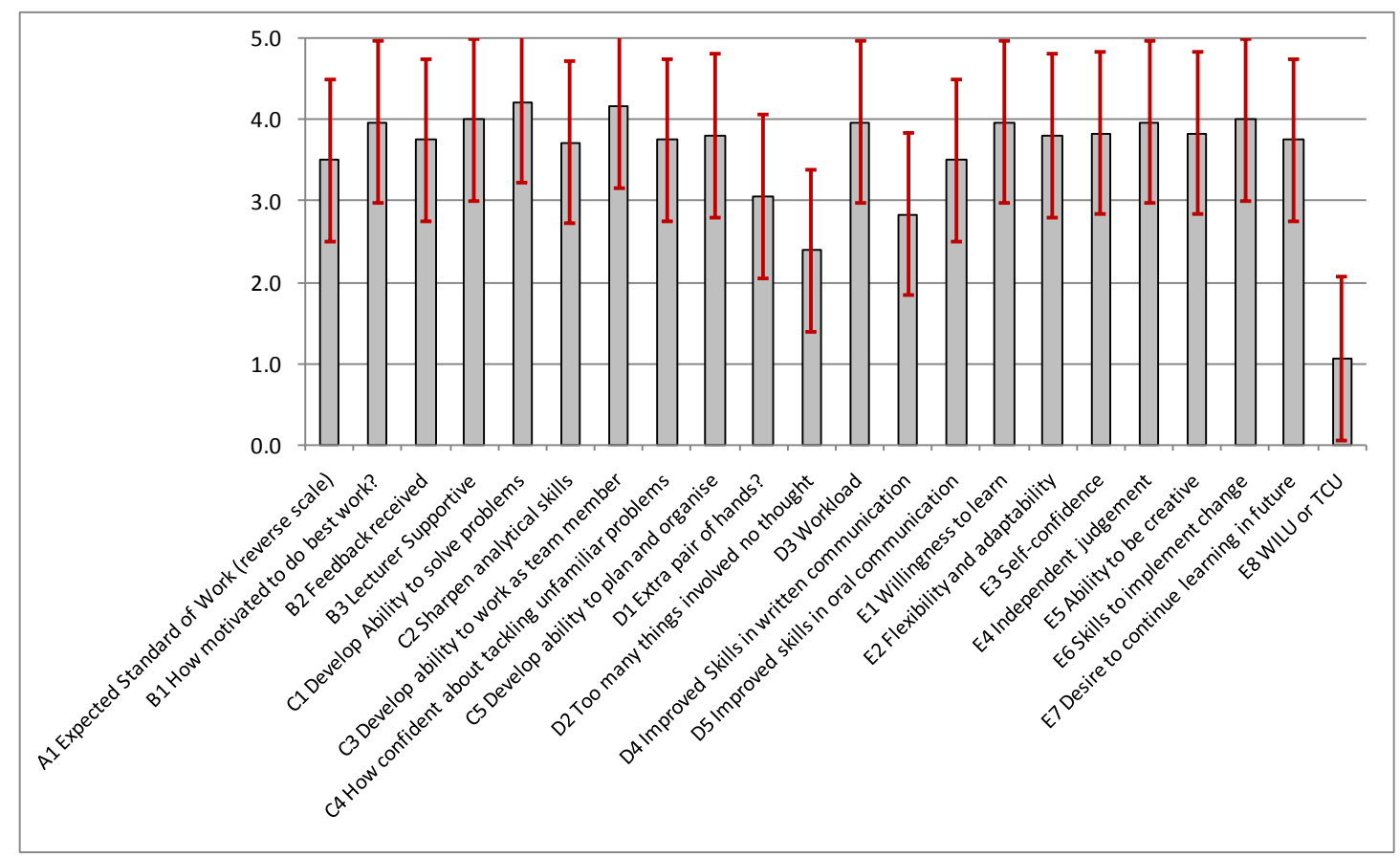

Fig. 2. Mean results from Likert questions with $95 \%$ confidence interval shown

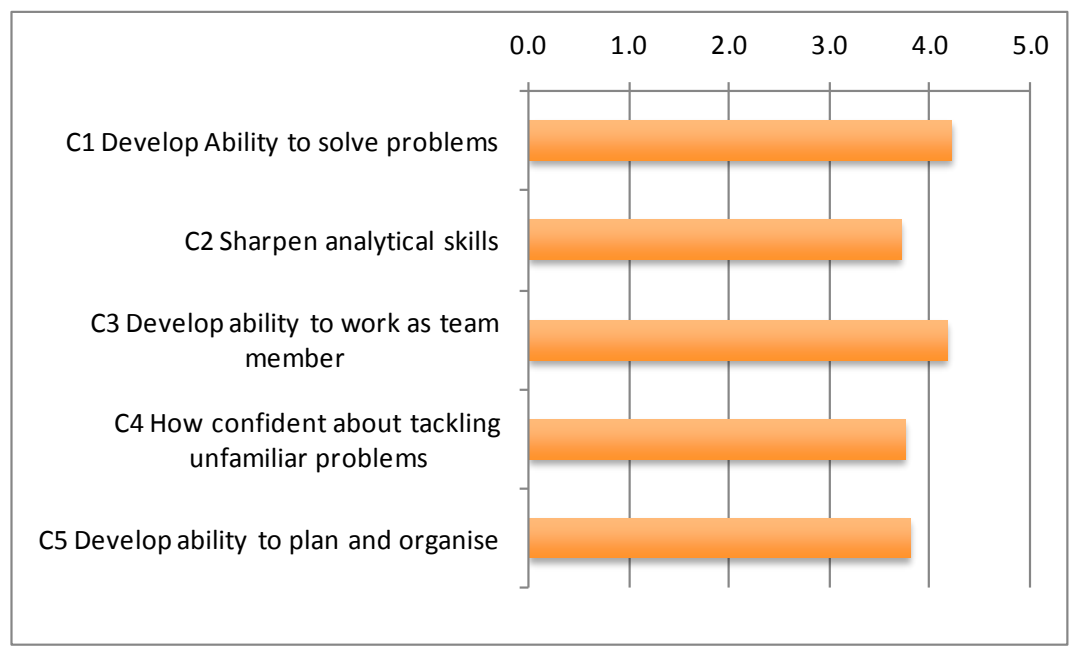

Fig. 3: Mean responses to Generic Skills questions

Apart from these survey data, the unit convener reports that student engagement is much higher in this WIL unit than in other TC units that he has taught. Students are much more motivated to take on tasks and solve problems that arise throughout the project. They show a high level of willingness to investigate reasons for problems and develop 'work-arounds' or other practical solutions for these real problems. Furthermore, students demonstrated a strong desire to work together and help each other out when one student was not as proficient in one area (e.g. video production/camera work or video editing) as another student. A comparison of this 
WIL unit and a 'real' TC unit in the area of video production and editing would be of benefit, however, was not available at the time when the WIL unit was taught.

Responses by clients have been unanimously positive, most notably evidenced by the fact that the TEDx Darwin 2011 organisers approached the unit convener again for the 2012 conference. From their point of view, benefits to the students are that students are exposed to the challenges of real world situations and actually having to solve the problems that occur. TEDx Darwin, for example, is a live recorded, one take, event which means when things go wrong (e.g. microphone drop-outs due to defect cable), students need to react instantly to find solutions (replace a non-working cheek microphone with hand-held microphone). Furthermore, backup procedures need to be in place in case of equipment failure (e.g. signal routing problems on audio mixing desk). The problem solving extends from the live event back into the classroom during the production of the final videos (e.g. showing a different camera angle because a camera operator was visible from another angle). The TEDx Darwin organiser states 'I am amazed at how the students have consistently been able to identify and overcome problems throughout the whole project' (personal correspondence).

From the point of a client organisation, benefits include early access to potential employees as well as a deeper connection between the organisation and the university as the major partner. This collaboration has helped to positively position TEDx Darwin within the community, including the speakers and audience who are very excited about the fact that the organisation works together with students and provides them with valuable industry experience.

\section{Discussion and conclusion}

This study sought to assess the merits and outcomes from the application of WIL teaching methods to a New Media course run at Charles Darwin University from 2010 to 2011. Our results suggest that overall, student, convener and client responses were largely positive and in favour of a WIL approach, at least in this area. Perhaps the most notable result is that, despite the fact that students responded that they perceived the workload of the WIL unit to be higher than in a TCU, 94\% of them still preferred the WIL unit.

While the sample size to date is relatively small, the data provides early indications about student preferences and their perceptions of successful outcomes from the application of the WIL approach. This is particularly the case for the development of generic skills including developing student's abilities for problem solving and for working as part of a team. Apart from the questionnaire, students were given a form where they assessed each other (as part of the grading). In this peer-review, students reported that the WIL unit was very useful to their development of team working abilities. As one student put it: 'One thing about our team was the laughter we had despite the hours we were putting into the project and we really bonded, always taking responsibility for the work at hand'. These skills are highly valued by employers and on this basis, the study here supports Freestone et al.'s (2007) and 
others' contentions of WIL having the potential to provide significant improvements to student motivation, engagement and overall learning at university. With continued data collection, the sample size will be built, and we envisage that these student evaluations will become a useful resource for ongoing analysis. We believe the research would, moreover, benefit from follow-up contact one to two years after students have undertaken the unit in order to obtain perceptions of the unit in retrospect and how it has helped them (or not) in their career and personal development. For this, ethical clearance would have to be sought in order to contact students. In conclusion, we believe WIL teaching at higher educational level seems to offer benefits that not only complement TC units, but also teach skills that TC units may not be able to provide as easily.

\section{Endnote}

\section{Questionnaire used in this study}

Name of Unit: NMD302 - New Media Advanced Studio

Dear Student,

You have participated in a unit that used the so-called Work-Integrated-Learning approach, where unit topics were directly linked to tasks in a real-world research project. This questionnaire seeks to collect your feedback to this approach and in the below questionnaire we refer to the Work-Integrated-Learning unit as WILU and a traditional coursework unit as TCU. Please keep in mind that when we are talking about a 'traditional' unit we refer to a regular coursework unit that uses textbooks, lectures and other sources to teach the learning matter.

\section{Biographical details}

Age:

Gender:

English first, second or other language:

\section{Section A - Unit Goals}

A1 - As compared to a TCU (Traditional Coursework Unit), the expected standard of work in this WILU (Work-Integrated-Learning Unit) has been

$\begin{array}{cccc}\square & \square & \square & \square \\ \begin{array}{c}\square \text { Much easier } \\ \text { to }\end{array} & \begin{array}{c}\text { Easier to } \\ \text { understand }\end{array} & \begin{array}{c}\square \\ \text { same as in }\end{array} & \text { Harder to } \\ \text { understand } & \text { a TCU } & \text { understand } & \text { Much } \\ \text { harder to } \\ \text { understand }\end{array}$

\section{Section B - Support for learning}

B1 - How motivated were you to do your best work in this WILU as compared to a TCU?

$\begin{array}{ccccc}\square & \square & \square & \square & \square \\ \text { Much less } & \text { Less } & \text { More } & \text { Much more } \\ \text { motivated } & \text { motivated } & \text { same as in } & \text { motivated } & \text { motivated } \\ \text { than in a } & \text { than in a } & \text { a TCU } & \text { than in a } & \text { than in a } \\ \text { TCU } & \text { TCU } & & \text { TCU } & \text { TCU }\end{array}$

B2 - How would you rate the feedback that you received for your work in this WILU as compared to a TCU? 


$\begin{array}{ccccc}\square & \square & \square & \square & \square \\ \text { Much less } & \text { Less } & \text { About the } & \text { More } & \text { Much more } \\ \text { feedback } & \text { feedback } & \text { same as in } & \text { than in a } & \text { feedback } \\ \text { than in a } & \text { than in a } & \text { a TCU } & \text { TCU } & \text { TCU in a } \\ \text { TCU } & \text { TCU } & \end{array}$

B3 - How supportive was your lecturer in this WILU as compared to a TCU?

$\begin{array}{ccccc}\square & \square & \square & \square & \square \\ \text { Much less } & \text { Less } & \text { About the } & \text { More } & \text { Much more } \\ \text { supportive } & \text { supportive } & \text { same as in } & \text { supportive } & \text { supportive } \\ \text { than in a } & \text { than in a } & \text { a TCU } & \text { TCU } & \text { than in a } \\ \text { TCU } & \text { TCU } & & \text { TCU }\end{array}$

Section C - Generic Skills

C1 - How did this WILU develop your ability to solve problems as compared to a TCU?

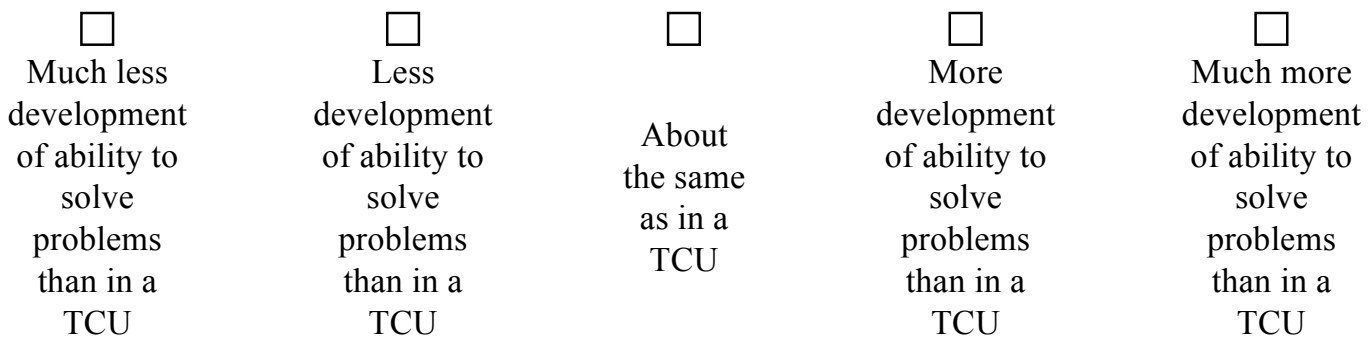

C2 - To which degree did this WILU sharpen your analytical skills as compared to a TCU?

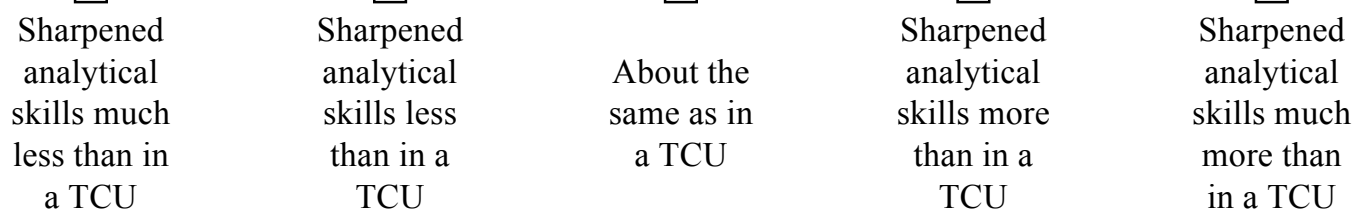

C3 - How did this WILU develop your ability to work as a team member as compared to a TCU?

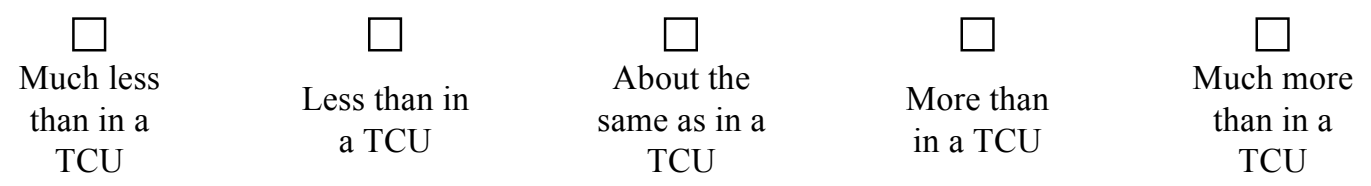

C4 - How confident do you feel about tackling unfamiliar work-based problems after attending this WILU as compared to attending a TCU?

$\begin{array}{ccccc}\square & \square & \square & \square & \square \\ \text { Much less } & \text { Less } & \text { About the } & \text { More } & \text { Much more } \\ \text { confident } & \text { confident } & \text { same as in } & \text { than in a } & \text { confident } \\ \text { than in a } & \text { than in a } & \text { a TCU } & \text { TCU } & \text { TCU in a } \\ \text { TCU } & \text { TCU } & & \end{array}$

C5 - How did this WILU help you develop the ability to plan and organise your day-to-day works as compared to a TCU? 


\begin{tabular}{|c|c|c|c|}
\hline $\begin{array}{l}\text { Much less } \\
\text { than in a } \\
\text { TCU }\end{array}$ & $\begin{array}{l}\text { Less than in } \\
\text { a TCU }\end{array}$ & $\begin{array}{c}\text { About the } \\
\text { same as in a } \\
\text { TCU }\end{array}$ & $\begin{array}{l}\text { More than } \\
\text { in a TCU }\end{array}$ \\
\hline
\end{tabular}

\section{Section D - Tasks}

D1 - In this WILU I was seen as an extra pair of hands rather than as a developing professional.

\begin{tabular}{|c|c|c|c|}
\hline $\begin{array}{l}\text { Strongly } \\
\text { disagree }\end{array}$ & Disagree & Neutral & Agree \\
\hline
\end{tabular}

D2 - In this WILU I was asked to do too many things that involve no thought.

\begin{tabular}{|c|c|c|c|c|}
\hline $\begin{array}{l}\text { Strongly } \\
\text { disagree }\end{array}$ & Disagree & Neutral & Agree & $\begin{array}{c}\text { Strongly } \\
\text { Agree }\end{array}$ \\
\hline
\end{tabular}

D3 - The workload in this WILU was

$\begin{array}{ccccc}\square & \square & \square & \square \\ \begin{array}{c}\text { Much less } \\ \text { than in a }\end{array} & \text { Less than in } & \text { About the } & \text { More than } & \text { Much more } \\ \text { TCU } & \text { a TCU } & \text { same as in a } & \text { in a TCU } & \text { than in a }\end{array}$

D4 - This WILU has improved my skills in written communication.

$\begin{array}{ccccc}\square & \square & \square & \square & \square \\ \begin{array}{c}\text { Much less } \\ \text { than in a }\end{array} & \text { Less than in } & \text { About the } & \text { More than } & \text { Much more } \\ \text { TCU } & \text { a TCU } & \text { same as in a } & \text { in a TCU } & \text { than in a }\end{array}$

D5 - This WILU has improved my skills in oral communication.

$\begin{array}{ccccc}\square & \square & \square & \square \\ \begin{array}{c}\text { Much less } \\ \text { than in a }\end{array} & \text { Less than in } & \text { About the } & \text { More than } & \text { Much more } \\ \text { TCU } & \text { a TCU } & \text { same as in a } & \text { in a TCU } & \text { than in a } \\ & & \text { TCU } & \text { TCU }\end{array}$

\section{Section E - Generic Skills}

To what extent do you feel that you have developed each of the following attributes

E1 - A willingness to learn.

\begin{tabular}{|c|c|c|c|c|}
\hline $\begin{array}{c}\text { Much less } \\
\text { than in a } \\
\text { TCU }\end{array}$ & $\begin{array}{l}\text { Less than } \\
\text { in a TCU }\end{array}$ & $\begin{array}{l}\text { About the } \\
\text { same as in } \\
\text { a TCU }\end{array}$ & $\begin{array}{l}\text { More than } \\
\text { in a TCU }\end{array}$ & $\begin{array}{l}\text { Much } \\
\text { more than } \\
\text { in a TCU }\end{array}$ \\
\hline
\end{tabular}

E2 - Flexibility and adaptability

Much less than in a TCU
Less than in a TCU
About the same as in a TCU
More than in a TCU
Much more than in a TCU 
E3 - Self-confidence

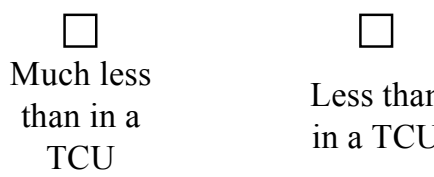
About the same as in a TCU

More than

Much in a TCU

E4 - Independent judgement

Much less than in a

TCU
Less than in a TCU
About the same as in a TCU
More than in a TCU
Much more than in a TCU

E5 - Ability to be creative

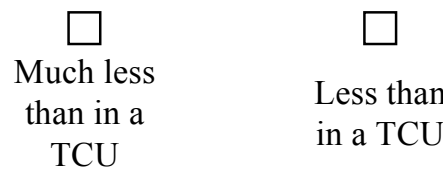

E6 - Skills to implement change
About the same as in a TCU
More than in a TCU
Much more than in a TCU<smiles>CC1(C)CCC1</smiles>
than in a

TCU
Less than in a TCU
About the same as in a TCU
More than in a TCU
Much more than in a TCU

E7 - A desire to continue learning in the future

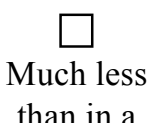

than in a

TCU
Less than

in a TCU
About the same as in a TCU
More than in a TCU
Much more than in a TCU

E8 - Overall, which teaching style do you prefer in terms of experiences and knowledge to support you in finding employment in the creative arts industry?

\section{Acknowledgements}

The authors would like to thank Bill Wade and Nicole Manapol for feedback and support as well as the real-world 'clients' who trusted our students to work on their projects.

\section{Works cited}

Bates, Merelyn 2008 'Work-integrated curricula in university programs' Higher Education Research \& Development 27: 4, 305-317 doi:10.1080/07294360802406775

Billett, Stephen \& A Henderson 2011 Developing learning professionals Springer Netherlands. doi:10.1007/978-90-481-3937-8_1 ISBN: 978-90-481-3937-8

Cooper, Lesley, J Orrell \& M Bowden 2010 Work integrated learning: A guide to effective practice New York: Routledge ISBN: 0415556775 
Dewey, John 1998 Experience and education Indianapolis, Indiana: Kappa Delta Pi

Draper, Paul, \& M Hitchcock 2006 'Work-integrated learning in music technology: Lessons learned in the creative industries' Asia-Pacific Journal of Cooperative Education 7: 2, 24-31

Franz, Jill M 2007 Work integrated learning for design : A scholarship of integration University of New South Wales

Freestone, Robert, P Williams, S Thompson \& K Trembath 2007 'A quantitative approach to assessment of work-based learning outcomes: an urban planning application' Higher Education Research \& Development 26: 4, 347-361

Gardner, Henry \& M Martin 2007 'Analyzing Ordinal Scales in Studies of Virtual Environments: Likert or Lump It' Presence: Teleoperators \& Virtual Environments 16: 4, 439-446

Harvey, Lee \& P T Knight 1996 Transforming higher education Open University Press, Taylor \& Francis, Bristol

Mellor, Antony 1991 'Experiential learning through integrated project work: An example from soil science' Journal of Geography in Higher Education 15: 2, 135-149

Orrell, Janice 2004 'Work-integrated learning programmes: Management and educational quality' Proceedings of the Australian Universities quality forum 2004

Patrick, Carol-Joy, D Peach, C Pocknee, F Webb, M Fletcher, G Pretto 2008 The WIL (Work Integrated Learning) report: a national scoping study http://eprints.qut.edu.au/44065/ Accessed on 22 May 2012

Taylor, Andrew 2012 'More than mobile: Migration and mobility impacts from the 'technologies of change' for Indigenous communities in the remote Northern Territory of Australia' Mobilities 7:2 doi:10.1080/17450101.2012.654997

Weisz, Miriam \& S Smith 2005 'Critical changes for successful cooperative education' Higher Education Research and Development Society of Australia (HERDSA) 